\title{
A Preface: How Ethics Failed: Lessons for Public Health for all Time
}

\author{
Martin McKee, CBE, MD, DSc ${ }^{1}$
}

Recommended Citation: McKee M. A preface: how ethics failed: lessons for public health for all time. Public Health Reviews. 2012;34: epub ahead of print.

I had not anticipated how difficult it would be to write a preface for the deeply moving paper by Jutta Lindert and colleagues in this volume. ${ }^{1}$ They describe events that took place before I was born, but which have shaped the values and beliefs that have underpinned my approach to the subject that has dominated my work for three decades, the health of the people of Europe. These events were, indisputably, unique. The Nazi regime fomented, incited, and carried out the killing of handicapped children and adults on an industrial scale, exploiting the latest advances in science and engineering to do so. It justified this with a perverted medical and scientific logic, that extermination of people with disabilities was "compassionate". No-one since then has attempted to do the same. Those who led the mass killings in Rwanda and Cambodia never sought to justify them in this way.

Yet we cannot ignore some parallels. I first visited Auschwitz in the early 1990s and even today the memory remains fresh in my mind. Everyone who visits a concentration camp will view it through their own private lens, shaped by their personal experiences and those of their families. In my case, my reaction was shaped by the fact that, a few weeks previously, I had been in Sarajevo, then a city under siege, offering what little support I could on behalf of the United Kingdom's Department for International Development. Of course, I am not suggesting that the Holocaust and the siege of Sarajevo were the same. That would be ridiculous. But subsequent scenes from the Bosnian town of Srebrenica cannot fail to remind us of events in the Third Reich.

\footnotetext{
${ }^{1}$ Professor of European Public Health, London School of Hygiene and Tropical Medicine, London, UK.
} 
More recently, I have been researching the health effects of the current economic crisis. In particular, I have been calling attention to the plight of the people of Greece. ${ }^{2}$ They are suffering from the effects of austerity imposed upon them, albeit in circumstances brought about substantially by the actions of their previous political leaders. Certainly, what is happening in Greece is different from what happened in Bosnia and in Nazi Germany. But there are some obvious parallels between the events of Kristallnacht in Nazi Germany and attacks by neo-Nazis on immigrants in Greece.

So while all of these events were different, they were also, in some ways, similar. So many people who could have done something did not. Lindert and her colleagues remind us, "The sad, historical fact is that the medical profession did nothing to resist the propaganda of the regime or its laws and decrees, by which human beings were deemed unworthy of life and unworthy of protection." The same was true in Bosnia with the rest of the world implicitly endorsing Otto von Bismarck's view that "Der ganze Balkan ist nicht die gesunden Knochen eines einzigen pommerschen Grenadiers wert" (The whole of the Balkans is not worth the bones of a single Pomeranian grenadier). ${ }^{3}$

Sadly, in all of these cases, the public health community has often been especially silent, or actually complicit in what was taking place, as happened in the Third Reich, where the physician, Arthur Guett, Director of Public Health in the Reich Interior Ministry, set out the official policy as "the supreme duty of a national state to grant life and livelihood only to the healthy and hereditarily sound portion of the people in order to secure the maintenance of a hereditarily sound and racially pure folk for all eternity" and where Arthur Greiser, the Nazi governor in north-western Poland, sought to prevent transmission of tuberculosis to Germans by exterminating infected Poles. ${ }^{4}$ And as Lindert et al. point out, this was used to justify the gas chambers of Auschwitz and the many other death camps.

But there were exceptions, and Lindert and colleagues remind us of those who acted in various ways, whether to confront the regime openly, such as those in the White Rose resistance group who paid with their lives, or others who, less publicly, used their position to save their patients. The same was true in the Yugoslav wars where, although the risks were much less, and in many other locations in Africa and in Asia where incitement and murder are common in the name of religion or simple racial hatred. Public health does have heroes and we should celebrate them.

The Greek philosopher Heraclitus notes how "you can never step twice into the same river". ${ }^{5}$ The circumstances, into which fate places us, as public health professionals in successive generations, are different. But the 
moral imperatives are constant. Lindert and her colleagues have given us a timely reminder, in a Europe witnessing the ascent of neo-fascism and xenophobia, of why we must learn the lessons of history and why we cannot and must not remain silent when others seek to divide us from our fellow human beings and as Lindert states, humiliate, separate and murder the "others".

\section{REFERENCES}

1. Lindert J, Stein Y, Guggenheim H, Jaakkola JK, Strous RD. How ethics failed - the role of psychiatrists and physicians in Nazi programs from exclusion to extermination, 1933-1945. Public Health Rev. 2012;34 epub ahead of print.

2. Kentikelenis A, Karanikolos M, Papanicolas I, Basu S, McKee M, Stuckler D. Health effects of financial crisis: omens of a Greek tragedy. Lancet. 2011;378: 1457-8.

3. Ludwig, E. Bismarck: The Story Of A Fighter. New York (NY): Little, Brown; 1927. p.511.

4. McKee M. A crisis of governance? J Public Health (Oxf). 2007;29:3-8. 